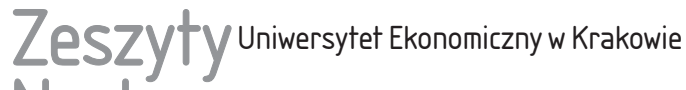 Naukowe
}

$8(932)$

ISSN 1898-6447

Zesz. Nauk. UEK, 2014; 8 (932): 141-152

DOI: 10.15678/ZNUEK.2014.0932.0810

Artur Walasik

Katedra Finansów

Uniwersytet Ekonomiczny w Katowicach

\section{Demografia fiskalna. Optymalny demograficznie system podatkowy}

\section{Streszczenie}

Ekonomiczne skutki procesów demograficznych (przede wszystkim rosnącego obciążenia demograficznego) wymagają rozważenia kryteriów implementacji zasady równego opodatkowania. Wobec zwiększania się politycznej dominacji osób w wieku emerytalnym konieczna staje się fiskalna ochrona osób wychowujących dzieci w związku z obciążeniem ich dochodów nie tylko składkami emerytalnymi, ale także podatkami stanowiącymi źródło finansowania deficytu systemu emerytalnego. Dochód tych osób jest również źródłem finansowania konsumpcji dzieci.

Respektowanie zasady równego opodatkowania w warunkach starzejącego się społeczeństwa wymaga więc rekonstrukcji podatku od dochodów osobistych lub podatków konsumpcyjnych. W przypadku opodatkowania dochodów osobistych niezbędne jest zastosowanie preferencyjnych rozwiązań pozwalających zmniejszyć ciężar podatkowy osób wychowujących dzieci w związku z mniejszą zdolnością do ponoszenia ciężaru fiskalnego. W przypadku opodatkowania konsumpcji akceptacja zasady równego opodatkowania będzie się wyrażać w niższym opodatkowaniu lub nawet zwolnieniu z opodatkowania dóbr konsumowanych przez dzieci.

Słowa kluczowe: demografia fiskalna, optymalny system podatkowy, zasada równego opodatkowania, przejście demograficzne.

\section{Wprowadzenie}

Postępujący proces starzenia się społeczeństwa wymaga rozstrzygnięcia licznych nowych kwestii związanych z finansami publicznymi. Niewątpliwe jest 
oddziaływanie procesów demograficznych na równowagę systemu zabezpieczenia emerytalnego. Zmiany w strukturze demograficznej współczesnych społeczeństw powodują wzrost wydatków systemów emerytalnych z tytułu płatności na rzecz osób osiągających wiek emerytalny. Równocześnie ograniczony przyrost liczby osób w wieku produkcyjnym, zobowiązanych do płatności na rzecz funduszy zabezpieczenia emerytalnego, powoduje zwiększenie deficytu sektora finansów publicznych. Przy założeniu, że predyktywne procesy demograficzne w najbliższych dekadach powodować będą utrzymywanie się deficytu finansów zabezpieczenia emerytalnego, równowaga systemu finansów publicznych determinowana jest zarówno zdolnością do przyrostu długu publicznego, jak i wydajnością fiskalną systemów podatkowych.

Przedmiotem opracowania jest określenie zależności między zachodzącymi procesami demograficznymi a równowagą finansów publicznych. Celem jest określenie kryteriów optymalizacji systemu podatkowego w kontekście coraz większych potrzeb finansowania deficytu finansów systemu emerytalnego w warunkach ograniczonych możliwości przyrostu długu publicznego.

\section{Wpływ procesów demograficznych na struktury fiskalne}

Inspiracją do podjęcia badań związanych z analizą wpływu procesów demograficznych na struktury fiskalne jest sformułowana w 1918 r. przez J.A. Schumpetera [1954] potrzeba stworzenia nowej dyscypliny wiedzy socjologii fiskalnej, przydatnej dla zrozumienia natury funkcjonowania współczesnego państwa z punktu widzenia współistnienia sfery gospodarczej, politycznej oraz społecznej. A. Glapiński przywołuje opinię J.A. Schumpetera: „finanse publiczne są jednym z najlepszych punktów obserwacyjnych do badania społeczeństwa, a zwłaszcza, choć nie tylko, jego życia politycznego" [2004, s. 206-207] i zauważa [2004, s. 212] swego rodzaju epistemologiczną dychotomię badania relacji między systemami: finansów publicznych oraz społecznym. Przyczyny społecznych roszczeń wobec wydatków publicznych wymagają zaangażowania aparatu socjologii, a wyjaśnienie stagnacji dochodów podatkowych kieruje zainteresowanie na metodologię nauk ekonomicznych.

Demografię fiskalną rozumieć należy jednak w odwrotnym ujęciu, tj. oddziaływania procesów i zjawisk ludnościowych na funkcjonowanie systemu fiskalnego, tak więc zarówno wydajności poszczególnych podatków oraz systemu podatkowego jako całości, jak i popytu na dobra publiczne oraz społeczne finansowane ze środków publicznych.

Starzenie się społeczeństwa jest charakterystyczne dla ostatniej fazy procesu przejścia demograficznego i ma odzwierciedlenie w systematycznym wzroście 
odsetka osób starych w populacji, czemu odpowiada również stopniowy wzrost wskaźnika A. Sauvy'ego, tzw. wskaźnika starości stanowiącego stosunek osób w wieku 60 i więcej lat do liczby osób w wieku do 19 lat [Okólski i Fihel 2012, s. 145-146]. Proces przejścia demograficznego rozumiany jest jako transformacja struktury wiekowej społeczeństwa, wynikającej z poprzedzającego spadek rozrodczości spadku umieralności. Towarzyszące tym przesuniętym w czasie procesom demograficznym wydłużenie się przeciętnej długości życia oraz zmniejszenie przyrostu naturalnego przyczyniają się do wzrostu udziału w strukturze wiekowej społeczeństwa osób starszych. W teorii przejścia demograficznego proponuje się typologię populacji ze względu na stopień starzenia się społeczeństwa (tabela 1).

Tabela 1. Typy społeczeństwa ze względu na stopień starzenia się

\begin{tabular}{|l|c|c|}
\hline \multirow{2}{*}{\multicolumn{1}{|c}{ Typ populacji }} & \multicolumn{2}{c|}{ Charakterystyka } \\
\cline { 2 - 3 } & mediana wieku (w latach) & $\begin{array}{c}\text { udział ludności w wieku } \\
\text { powyżej 60 lat (w \%) }\end{array}$ \\
\hline Bardzo młoda & $15-19$ & poniżej 5 \\
\hline Młoda & $20-24$ & $5-9$ \\
\hline Starzejąca się & $25-29$ & $10-14$ \\
\hline $\begin{array}{l}\text { Zaawansowana w procesie } \\
\text { starzenia (stara) }\end{array}$ & $30-34$ & $15-19$ \\
\hline Bardzo stara & 35 i więcej & 20 i więcej \\
\hline
\end{tabular}

Źródło: [Teoria przejścia demograficznego 1990, s. 267].

Przejście demograficzne w aspekcie zasady efektywności okazuje się realizować według schematu uzyskania określonego efektu przy mniejszych nakładach. Jak trafnie zauważa M. Okólski [2004, s. 23], „to, że taki sam efekt w sensie biologicznym (liczba ludności i jej kompozycja demograficzna) może być osiągnięty kosztem zasadniczo odmiennej płodności, wynika z różnic w długości życia ludzi”. W konsekwencji proces przejścia demograficznego powoduje przejście od warunków reprodukcji rozrzutnej do reprodukcji oszczędnej. Kompletny przegląd teorii przejścia demograficznego zawiera opracowanie D. Kirka [1996].

Zmiany struktury wiekowej społeczeństwa nie pozostają bez znaczenia dla wydajności fiskalnej poszczególnych podatków, a w konsekwencji również dla równowagi systemu finansów publicznych, w szczególności jeśli chodzi o zdolność systemu podatkowego do finansowania wydatków publicznych. Konieczne staje się więc wskazanie dwóch aspektów analizy wpływu procesów demograficznych na struktury fiskalne - po pierwsze zróżnicowanych konsekwencji zmian demograficznych dla wydajności fiskalnej poszczególnych podatków, a po drugie - ryzyka wahań dochodów podatkowych wywołanych różnym tempem, a także odmiennymi kierunkami zmian dochodów realizowanych z poszczególnych podatków. 
W literaturze przedmiotu [Nyce i Schieber 2011] dostrzega się i poddaje szczegółowej analizie zależności między zmianami w strukturze wiekowej społeczeństwa a równowagą systemów emerytalnych oraz wpływ starzenia się społeczeństwa na poziom i strukturę wydatków publicznych. Redystrybucyjna aktywność władzy publicznej rozważana jako sposób rozwiązywania konfliktu interesów różnych grup społecznych pozwala dalej, na co wskazują T. Persson i G. Tabellini [2000, s. 117-118], zidentyfikować cztery podstawowe schematy redystrybucji: między osobami bogatymi i biednymi, młodszymi i starszymi, mieszkającymi w bogatszych i biedniejszych regionach oraz zatrudnionymi i bezrobotnymi. Według wspomnianych autorów system ubezpieczeń społecznych ogranicza demograficznie indukowane napięcie redystrybucyjne [Persson i Tabellini 2000, s. 123-132].

Nie negując znaczenia systemów emerytalnych, szczególną uwagę należy poświęcić analizie determinowanej demograficznie fiskalnej wydajności systemów podatkowych, co wynika z potrzeby uwzględnienia zmienności w czasie życia relacji zachodzących między wysokością osiąganych dochodów oraz poziomem realizowanych wydatków konsumpcyjnych. Najogólniej można przyjąć, że w długim okresie (rys. 1) zmienność dochodów (linia ciągła) jest większa niż odpowiadający jej rozkład w czasie poziomu konsumpcji (linia przerywana).

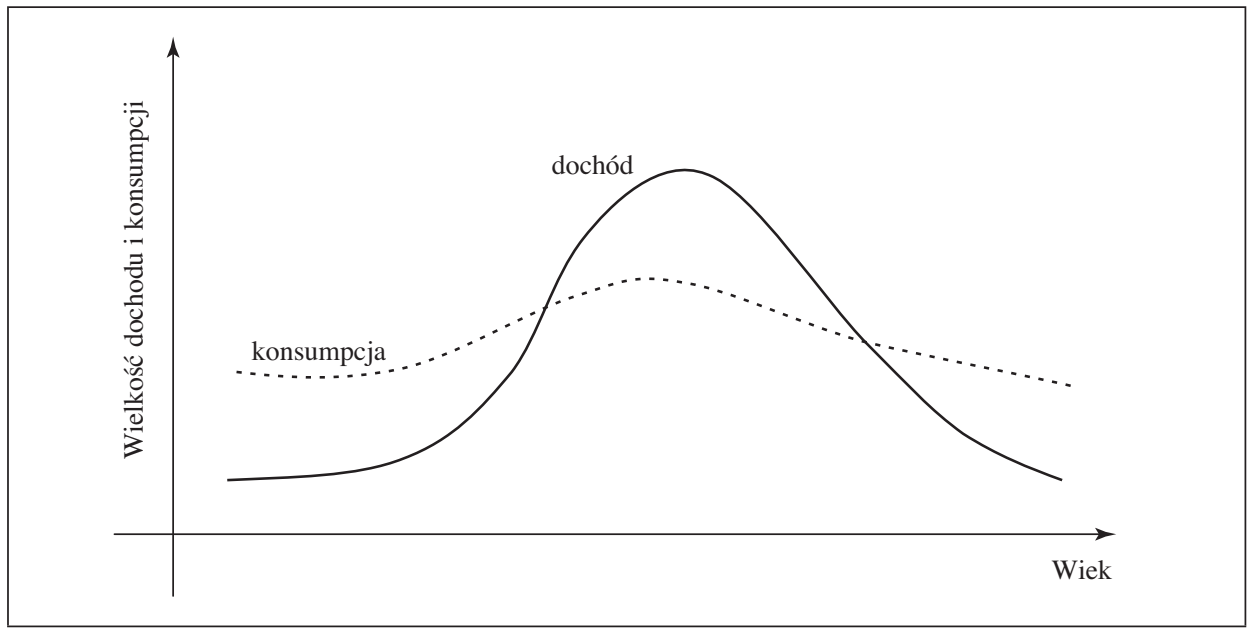

Rys. 1. Zmiany dochodu i konsumpcji w czasie trwania życia

Źródło: opracowanie własne.

Rozróżnienie skutków opodatkowania dochodów oraz konsumpcji w zależności od decyzji ekonomicznych podatnika, związane z poszukiwaniem właściwego wskaźnika do oceny równego opodatkowania, zaproponował w swoim 
opus magnum R.A. Musgrave [1959, s. 161-164], stwierdzając, że opodatkowanie konsumpcji będzie preferowane przez podatników, którzy mają wyższą skłonność do oszczędzania; natomiast opodatkowaniu dochodów sprzyjać będą podatnicy, których charakteryzuje większa skłonność do konsumpcji.

W kontekście rozłożenia ciężaru fiskalnego między osoby w różnym wieku niższe obciążenia fiskalne dochodów osobistych rekompensowane wyższym opodatkowaniem konsumpcji będą niekorzystne dla osób rozpoczynających pracę oraz osób w wieku emerytalnym. Osoby z pierwszej grupy wiekowej realizują stosunkowo wysoką konsumpcję, dzięki zaciąganym kredytom. W takim przypadku wysokie opodatkowanie dochodów staje się niekorzystne co najmniej z dwóch powodów: po pierwsze zmniejsza się zdolność do konsumpcji finansowanej z dochodu po opodatkowaniu, po drugie ograniczona zostaje zdolność kredytowa podatnika. W przypadku osób w wieku emerytalnym wysokie podatki konsumpcyjne są niekorzystne ze względu na to, że większość konsumpcji finansowana jest oszczędnościami realizowanymi poprzez wypłacane emerytury lub spieniężone inwestycje kapitałowe.

W konsekwencji z perspektywy wydajności fiskalnej systemu podatkowego w społeczeństwach z dominującą w strukturze wiekowej grupą osób aktywnych zawodowo zwiększa się wydajność fiskalna podatków dochodowych w stosunku do podatków konsumpcyjnych. Wiąże się to z relatywnie większą skłonnością do oszczędzania osób w tym wieku oraz z ograniczonymi możliwościami konsumpcji w związku ze spłatą zaciągniętych wcześniej kredytów. Natomiast, jak podkreślają S.A. Nyce oraz S.J. Scheiber [2011, s. 48], w związku ze starzeniem się społeczeństwa i towarzyszącym temu wzrostem obciążenia demograficznego zmienią się proporcje osób, które będą jedynie konsumować, nie przyczyniając się do łącznej produktywności społeczeństwa.

\section{Optymalny demograficznie system podatkowy}

Teorii finansów publicznych nie jest obce poszukiwanie atrybutów określających optymalny system podatkowy. Za rezultaty tego rodzaju poszukiwań mogą zostać uznane zbiory zasad podatkowych, wyznaczających cechy pożądanych systemów podatkowych. J. Alm [1996, s. 117] wskazuje, że kluczowym problemem ekonomiki sektora publicznego jest odpowiednia kompozycja podatków, która uwzględniać będzie wzajemnie ze sobą powiązane trzy cechy pożądanego systemu podatkowego, to jest jego efektywność fiskalną, równość rozłożenia ciężaru między podatników oraz prostotę minimalizującą zarówno koszty administracji podatkowej, jak i dodatkowe koszty dla podatników. 
Ogólnie rzecz ujmując, optymalizacja wymaga określenia celu podejmowanych rozwiązań. W przypadku budowy systemu podatkowego mogą to być w szczególności, jak wskazuje w swoim obszernym studium R.W. Tresch [2002, s. 332 i n.]: prostota administrowania, minimalizacja dodatkowych kosztów opodatkowania, wspieranie długoterminowego wzrostu gospodarczego, łagodzenie wahań koniunktury, implementacja społecznie pożądanych zasad równości lub sprawiedliwości.

J. Slemrod [1990, s. 157 i n.] wskazuje na dwa podejścia do kwestii optymalnego opodatkowania oraz optymalnego systemu podatkowego. Pierwsze podejście - normatywne, dominujące w latach 70 . oraz 80 . XX w., koncentrowało się na rozpoznaniu charakteru relacji zachodzących między zbiorem dostępnych władzy publicznej instrumentów podatkowych, strukturą gospodarki oraz celami polityki podatkowej. Drugie podejście - zasobowe, kładzie nacisk na identyfikację kosztów funkcjonowania aparatu administracji podatkowej pozostających w związku z oporem podatnika, wynikającym z przymusowego charakteru opodatkowania. W konsekwencji różne systemy podatkowe pozwalające zaspokajać w tych samych rozmiarach popyt władzy publicznej na pieniądz będą indukować różne co do wysokości koszty administracji podatkowej.

Optymalne opodatkowanie konsumpcji, jeśli uwzględnić podejście normatywne, prowadzić będzie do zróżnicowania wysokości stawek podatkowych dla poszczególnych dóbr, które charakteryzują się różną elastycznością cenową popytu (minimalizacja utraty dobrobytu wynikającego z utraty nadwyżki konsumenta). $\mathrm{Z}$ drugiej strony koszty administrowania tak złożonym systemem podatkowym uzasadniają unifikację stawki podatkowej. Jeśli wziąć pod uwagę zmienność w czasie struktury demograficznej podatników, optymalny demograficznie system podatkowy wymagać będzie oszacowania albo demograficznych kosztów opodatkowania przy założeniu dominacji zasady stałości opodatkowania w czasie, albo administracyjnych kosztów opodatkowania przy założeniu zmienności opodatkowania konsumpcji w zależności od zmian w strukturze wiekowej konsumentów.

Problem optymalizacji odnosi się również do zagadnień ludnościowych. E. Rosset [1983, s. 31] wskazuje, że problem „ludności optymalnej” należy rozpatrywać w kontekście historycznym, w związku z czym pojęcie optymalnej liczby i struktury populacji będzie determinowane postępem ekonomicznym i społecznym. Stąd jeżeli na początku dominują czynniki przyrodnicze, optymalna struktura ludności musi uwzględnić zdolność do prostego biologicznego przetrwania; z czasem wagi zaczynają nabierać czynniki polityczne, zmierzające do ustalenia struktury populacji zabezpieczającej istnienie państwa. Następnie wykształca się ideał stosunków społecznych, definiując optymalną strukturę demograficzną w kontekście sprawiedliwości społecznej i dobrobytu ludności. Przegląd doktryn ludności optymalnej przedstawia K.F. Zimmermann w redagowanej przez siebie pracy Economic Theory of Optimal Population [1989, s. 1-9], trafnie zwracając 
uwagę, że inna liczba i struktura populacji będzie optymalna z punktu widzenia maksymalizacji dochodu albo konsumpcji per capita, globalnego dochodu albo konsumpcji, oczekiwanej długości życia czy innych niż ekonomiczne kryteriów.

Zachodzące procesy demograficzne nadają dynamiczny charakter strukturom społecznym. Oznacza to również zmienność charakterystyk zbiorowości podatników, nie tylko ze względu na cechy demograficzne (wiek), lecz również ekonomiczne (skłonności do konsumpcji, zróżnicowania dochodów itd.). W związku z tym uzasadnione staje się dokonanie rewizji dezyderatów formułowanych w doktrynie finansów publicznych, w szczególności zasady równego opodatkowania. Konieczne będzie zwłaszcza określenie znaczenia charakterystyk demograficznych podatnika dla sposobu implementacji zasad korzyści oraz zdolności płatniczej względem opodatkowania dochodów osobistych oraz konsumpcji.

Władze publiczne przy projektowaniu systemów podatkowych nie mogą ograniczyć się do uwzględnienia wyłącznie gospodarczych interesów podatników oraz związku wydajności podatków z procesami gospodarczymi, co zwykło się wywodzić z koncepcji wyodrębnienia za A. Wagnerem [1958, s. 11] ekonomicznych zasad podatkowych. W warunkach nasilającego się obciążenia demograficznego oraz wrażliwości równowagi finansów publicznych na zmiany struktury wiekowej społeczeństwa projektowanie systemu podatkowego musi uwzględniać obok stricte ekonomicznych czynników również czynniki społeczne, w tym demograficzne.

Uznanie wieku za istotną determinantę indywidualnej sytuacji poszczególnych osób powoduje wprowadzenie w podatkach rozwiązań uwzględniających demograficzne, obok powszechnie stosowanych przy konstrukcji elementów technicznych podatku, ekonomicznych zmiennych charakteryzujących podatnika. W przypadku dwóch osób w tym samym wieku różniących się wyłącznie wysokością osiąganego dochodu zasada zdolności płatniczej pozwala uznać, że osoba osiągająca wyższy dochód jest w sytuacji pozwalającej uznać jej zdolność do zapłaty podatku za większą niż drugiej osoby (zasada pionowej równości opodatkowania w aspekcie ekonomicznym). Natomiast mając na uwadze wynikające z zasady zdolności płatniczej postulaty równego opodatkowania, należy rozstrzygnąć wątpliwości wynikające z pytania, czy podatnicy osiągający dochód w tej samej wysokości, ale różniący się wiekiem dysponują taką samą zdolnością do zapłaty podatku (zasada pionowej równości opodatkowania w aspekcie demograficznym).

System podatkowy neutralny demograficznie, który nie uwzględnia zróżnicowania wysokości opodatkowania w zależności od wieku podatnika, nie może zostać uznany za neutralny ekonomicznie. Równe co do wysokości podatki płacone od takiego samego dochodu przez osoby znajdujące się w odmiennej sytuacji ekonomicznej powodowanej ich wiekiem generować będą premię podatkową dla osób znajdujących się w okresie życia charakteryzującym się większą zdolnością do ponoszenia ciężarów fiskalnych. 


\section{Dezyderat równości systemu podatkowego w aspekcie demograficznym}

W perspektywie kolejnych dekad dobrobyt znacznej części społeczeństwa zależny będzie od malejącej grupy osób aktywnych zawodowo. Wskazane zjawisko pozostawać będzie konsekwencją nie tylko rosnącego obciążenia demograficznego wynikającego z wejścia w ostatnią fazę przejścia demograficznego, charakteryzującego się rosnącym udziałem osób starszych, lecz także opóźnienia wejścia w okres aktywności zawodowej osób młodszych, wynikającego z coraz większego znaczenia kapitału ludzkiego oraz większych oczekiwań co do jakości kształcenia.

Analiza rozkładu ciężaru podatkowego, istotna z perspektywy oceny implementacji zasady równości, wymagać będzie uwzględnienia różnych schematów opodatkowania grupy aktywnych i biernych zawodowo członków społeczeństwa. W przypadku grupy osób aktywnych zawodowo istotna będzie zdolność finansowania własnej konsumpcji z bieżącego dochodu. W przypadku osób biernych zawodowo relacja konsumpcji do osiąganego dochodu będzie kształtowała się inaczej dla osób młodszych, a inaczej dla osób starszych (tabela 2).

Tabela 2. Charakterystyka dochodu oraz konsumpcji w zależności od wieku

\begin{tabular}{|c|c|c|c|c|}
\hline $\begin{array}{l}\text { Wyszcze- } \\
\text { gólnienie }\end{array}$ & $\begin{array}{c}\text { Młode osoby } \\
\text { bierne zawodowo }\end{array}$ & $\begin{array}{c}\text { Osoby aktywne } \\
\text { zawodowo mające } \\
\text { na utrzymaniu } \\
\text { dzieci }\end{array}$ & \begin{tabular}{|c|} 
Osoby aktywne \\
zawodowo \\
niemające na \\
utrzymaniu dzieci
\end{tabular} & $\begin{array}{c}\text { Starsze osoby } \\
\text { bierne zawodowo }\end{array}$ \\
\hline Dochód & brak & tendencja rosnąca & wysoki & tendencja malejąca \\
\hline $\begin{array}{l}\text { Źródło } \\
\text { dochodu }\end{array}$ & brak & $\begin{array}{l}\text { przede wszystkim } \\
\text { praca }\end{array}$ & praca i kapitał & oszczędności \\
\hline Konsumpcja & rosnąca & $\begin{array}{l}\text { rosnąca, ale ogra- } \\
\text { niczana składkami } \\
\text { emerytalnymi oraz } \\
\text { spłatą zaciągnię- } \\
\text { tych kredytów }\end{array}$ & $\begin{array}{l}\text { wysoka, ale ogra- } \\
\text { niczana składkami } \\
\text { emerytalnymi } \\
\text { i dobrowolnymi } \\
\text { inwestycjami } \\
\text { kapitałowymi }\end{array}$ & malejąca \\
\hline $\begin{array}{l}\text { Źródła } \\
\text { finansowania } \\
\text { konsumpcji }\end{array}$ & dochód rodziców & $\begin{array}{l}\text { własny dochód } \\
\text { z pracy oraz zacią- } \\
\text { gane kredyty }\end{array}$ & $\begin{array}{l}\text { własny dochód } \\
\text { z pracy oraz } \\
\text { kapitału }\end{array}$ & $\begin{array}{l}\text { emerytury, ewen- } \\
\text { tualnie dochód } \\
\text { dzieci }\end{array}$ \\
\hline
\end{tabular}

Źródło: opracowanie własne.

Ewaluacja stosowania zasady równego opodatkowania dochodu wymagać będzie korekty wynikającej z obciążenia tego dochodu finansowaniem konsumpcji dzieci. W konsekwencji, by utrzymać właściwy rozkład ciężaru podatkowego, uzasadnione staje się wprowadzenie preferencyjnych rozwiązań przy opodatko- 
waniu dochodów osób wychowujących dzieci (np. iloraz rodzinny, ulga z tytułu wychowania dzieci) albo preferencyjne opodatkowanie lub zwolnienie z opodatkowania dóbr konsumowanych przez dzieci. Każda z propozycji dotyczy ingerencji w system podatkowy wynikającej z potrzeby uwzględnienia rosnącego znaczenia czynników demograficznych dla funkcjonowania systemu podatkowego respektującego zasadę równego opodatkowania. Miejscem ingerencji w przypadku pierwszej propozycji jest podatek od dochodów osobistych, w przypadku drugiej rekomendacji - podatek konsumpcyjny.

W przypadku rekonstrukcji podatku od dochodów osobistych uwzględniona zostaje zależna od wieku podatnika zdolność do ponoszenia ciężaru podatku. Jeśli respektować zasadę prostoty opodatkowania i związanej z tym zasady ograniczenia kosztów administrowania podatkiem, korzystniejszym rozwiązaniem jest wprowadzenie parametrów korygujących podstawę opodatkowania w formie ilorazu podatkowego albo stosowanie ulg podatkowych. Osoby posiadające dzieci i osiągające ten sam dochód mają obiektywnie mniejszą zdolność do ponoszenia ciężaru fiskalnego niż osoby, które albo jeszcze nie mają, albo już nie wychowują dzieci. W konsekwencji podatnicy o tym samym poziomie dochodu mogą mieć różną zdolność ponoszenia ciężaru fiskalnego w zależności od wieku. Zauważyć należy bowiem, że po osiągnięciu wieku prokreacyjnego wraz ze wzrostem wieku dzietność rośnie, po czym spada, aż do osiągnięcia poziomu zerowego po zakończeniu okresu prokreacyjnego.

Konsekwencją wprowadzenia wskazanych w artykule rozwiązań będzie zróżnicowanie relacji wysokości płaconego podatku od dochodów osobistych do poziomu osiąganego dochodu. W związku z istotnie zależnym od wieku rozkładem podatników mogących skorzystać ze wskazanych preferencji podatkowych stopa opodatkowania dochodów osobistych ustalona dla podatników osiągających ten sam dochód będzie wykazywała zmienność w stosunku do wieku podatnika. Udział osób wychowujących dzieci w finansowaniu konsumpcji osób starszych (emerytów) zależeć będzie od tego, w jaki sposób ustalona zostanie podstawa naliczania składek emerytalnych. Jeżeli będzie to dochód skorygowany w związku z zaproponowanymi w artykule preferencyjnymi rozwiązaniami (czyli np. dochód pomniejszony w stosunku do ilorazu lub zmniejszony o ulgę podatkową), to system podatkowy uwzględniać będzie jeszcze w większym stopniu czynniki demograficzne.

W przypadku drugiej propozycji, tj. zwolnienia lub niższego opodatkowania dóbr konsumowanych przez dzieci, w wymiarze ekonomicznym występuje dobrowolnie akceptowane przez rodziców przerzucenie na nich ciężaru opodatkowania konsumpcji ich dzieci. W konsekwencji, z uwzględnieniem indywidualnie kalkulowanej użyteczności konsumpcji, jeżeli wśród podatników osiągających dochód opodatkowany według tych samych zasad niektórzy finansują z tego dochodu 
konsumpcję dzieci, to uzyskiwana przez nich indywidualna użyteczność będzie różna. W przypadku osób wychowujących dzieci taki sam dochód pozwala na zaspokojenie na niższym poziomie indywidualnych potrzeb, tym samym równe opodatkowanie dóbr konsumowanych przez dzieci oraz osoby starsze byłoby sprzeczne z dezyderatem równego opodatkowania według zasady korzyści.

Postulat obniżenia podatków obciążających finansowaną z dochodów rodziców konsumpcję pozostających na ich wychowaniu dzieci nabiera jeszcze większego znaczenia w związku z procesem starzenia się społeczeństwa. Jak wskazuje bowiem H. Wikoszewski [Demographic Change... 2008, s. 176], rosnące politycznie znaczenie osób starszych, określane jako polityczny fenomen tzw. gerontokracji [Mulligan i Sala-i-Martin 1999, s. 11 i n.]), nie jest kompensowane udziałem w grupie wyborców niemających prawa głosu dzieci. Stąd systemy fiskalne w warunkach starzejącego się społeczeństwa podlegać będą presji transferu dochodu osób aktywnych zawodowo na rzecz osób w wieku emerytalnym, kosztem dzieci.

Dodatkowo w związku z transferami w obrębie systemu emerytalnego występuje przerzucenie ciężaru fiskalnego wynikającego z opodatkowania konsumpcji osób w wieku emerytalnym na osoby aktywne zawodowo, których część dochodu stanowi de facto źródło finansowania konsumpcji osób w wieku emerytalnym. Ponieważ głównym źródłem finansowania wydatków konsumpcyjnych przez starsze osoby są finansowane $\mathrm{z}$ bieżących składek emerytury, system fiskalny z wbudowanym systemem emerytalnym dokonuje przymusowego przerzucenia opodatkowania konsumpcji na wszystkie osoby aktywne zawodowo. Schematy przerzucenia podatku w przypadku konsumpcji dzieci oraz emerytów różnią się po pierwsze podmiotowym zakresem absorbujących ciężar fiskalny, po drugie charakterem tej absorpcji. W przypadku incydencji opodatkowania konsumpcji dzieci zakres podmiotowy ogranicza się do osób wychowujących dzieci; w przypadku incydencji opodatkowania konsumpcji emerytów zakres ten obejmuje wszystkie aktywne zawodowo osoby, niezależnie od tego, czy wychowują dzieci. Różnice w przerzuceniu ciężaru opodatkowania konsumpcji wyrażają się w jego przymusowym charakterze w przypadku konsumpcji osób starszych oraz dobrowolnością absorpcji przez rodziców ciężaru fiskalnego wynikającego z konsumpcji dzieci.

\section{Zakończenie}

Stanowiący historyczny precedens proces demograficznej transformacji, związany z przejściem od reprodukcji rozrzutnej (wysoka dzietność, wysoka umieralność) do reprodukcji oszczędnej (niska dzietność, niska umieralność), 
stanowi obecnie oraz będzie stanowił w najbliższych latach wyzwanie dla władz publicznych w zakresie rekonstrukcji systemu podatkowego. Respektowanie ekonomicznych skutków procesów demograficznych (przede wszystkim rosnącego obciążenia demograficznego) wymaga rozważenia kryteriów implementacji zasady równego opodatkowania.

Wobec zwiększającej się politycznej dominacji osób w wieku emerytalnym konieczna staje się fiskalna ochrona osób wychowujących dzieci, w związku z obciążeniem ich dochodów nie tylko składkami emerytalnymi, ale także podatkami stanowiącymi źródło finansowania deficytu systemu emerytalnego. Dochód tych osób jest również źródłem finansowania konsumpcji dzieci.

Respektowanie zasady równego opodatkowania w warunkach starzejącego się społeczeństwa wymaga więc rekonstrukcji podatku od dochodów osobistych lub podatków konsumpcyjnych. W przypadku opodatkowania dochodów osobistych niezbędne jest zastosowanie preferencyjnych rozwiązań pozwalających zmniejszyć ciężar podatkowy osób wychowujących dzieci w związku z mniejszą zdolnością do ponoszenia ciężaru fiskalnego. Stąd właściwe będzie płacenie przez osobę wychowującą dzieci niższego podatku dochodowego od takiego samego dochodu osiąganego przez osobę w wieku emerytalnym. Tym samym w optymalnym demograficznie systemie opodatkowania dochodów osobistych osoby w różnym wieku płacić powinny podatek w różnej wysokości od tego samego dochodu. W przypadku opodatkowania konsumpcji akceptacja zasady równego opodatkowania wyrażać będzie się w niższym opodatkowaniu lub nawet zwolnieniu z opodatkowania dóbr konsumowanych przez dzieci.

\section{Literatura}

Alm J. [1996], What Is an “Optimal” Tax System? „National Tax Journal”, nr 1.

Demographic Change and Intergenerational Justice [2008], ed. J.Ch. Tremmel, Springer, Berlin-Heidelberg.

Economic Theory of Optimal Population [1989], ed. K.F. Zimmermann, Springer, BerlinHeidelberg-New York.

Glapiński A. [2004], Kapitalizm, demokracja i kryzys państwa podatków, Szkoła Główna Handlowa, Warszawa.

Kirk D. [1996], Demographic Transition Theory, „Population Studies”, nr 3, http://dx.doi. org/10.1080/0032472031000149536.

Mulligan C.B., Sala-i-Martin X. [1999], Gerontocracy, Retirement, and Social Security, NBER Working Paper No. 7117.

Musgrave R.A. [1959], The Theory of Public Finance. A Study in Public Economy, McGraw-Hill, New York-Toronto-London.

Nyce S.A., Schieber S.J. [2011], Ekonomiczne konsekwencje starzenia się społeczeństw, Wydawnictwo Naukowe PWN, Warszawa. 
Okólski M. [2004], Demografia zmiany społecznej, Wydawnictwa Naukowe Scholar, Warszawa.

Okólski M., Fihel A. [2012], Demografia. Współczesne zjawiska i teorie, Wydawnictwo Naukowe Scholar, Warszawa.

Persson T., Tabellini G. [2000], Political Economics. Explaining Economic Policy, MIT Press, Cambridge-London.

Rosset E. [1983], Doktryna ludności optymalnej w rozwoju historycznym, PWE, Warszawa.

Schumpeter J.A. [1954], The Crisis of the Tax State, Macmillan, London-New York.

Slemrod J. [1990], Optimal Taxation and Optimal Tax Systems, „Journal of Economic Perspectives", nr 1, http://dx.doi.org/10.1257/jep.4.1.157.

Teoria przejścia demograficznego [1990], red. M. Okólski, PWE, Warszawa.

Tresch R.W. [2002], Public Finance. A Normative Theory, Academic Press, Amsterdam Wagner A. [1958], Three Extracts on Public Finance [w:] Classics in the Theory of Public Finance, Macmillan, London-New York.

\section{Fiscal Demography - A Demographically Optimal Tax System}

The economic impact of demographic processes (mainly the growing age dependency ratio) requires consideration of the criteria for the implementation of the principle of equal taxation. In a situation where people of pensionable age are politically dominant (gerontocracy) it becomes necessary to implement fiscal protection for parents. It is their incomes that are the source not only of pension contributions, but also of the taxes that finance the pension system deficit. The income of parents is also a very significant source of finance for their children's consumption. Respecting the principle of equal taxation according to the aging process requires the reconstruction of both personal income tax and consumption tax. The former requires the implementation of preferential solutions that reduce the tax burden on people bringing up children, who are less able to shoulder the fiscal burden. Reconstruction of the latter, meanwhile, would see acceptance of the principle of equal taxation expressed in a lower tax rate or even in exemption from taxation in the case of goods consumed by children.

Keywords: fiscal demography, optimal tax system, equal taxation, demographic transition. 